\title{
PENGEMBANGAN KONSERVATIF GAMES IN AQUATIC UNTUK PENINGKATAN KEBUGARAN JASMANI DAN SPORTIVITAS SISWA SEKOLAH DASAR
}

\author{
Bhayu Billiandri' $^{1)}$, Supriyono ${ }^{2)}$, Agus Pujianto ${ }^{3)}$, Bambang Priyono ${ }^{4)}$ \\ Pendidikan Jasmani Kesehatan dan Rekreasi Universitas Negeri Semarang \\ Email: ${ }^{1}$ bhayubilliandri@mail.unnes.ac.id \\ ${ }^{2}$ supriyonopjkr@mail.unnes.ac.id \\ 3 guspujianto.73@mail.unnes.ac.id \\ 4bambangpriyono@mail.unnes.ac.id
}

\begin{abstract}
ABSTRAK
Pendidikan Jasmani khususnya untuk peningkatan kesegaran jasmani jasmani , dalam aktivitas kegiatannya menerapkan Konservatif Games in Aquatic, sebagai solusi dari kegiatan Pendidikan Jasmani dalam proses pembelajaran di sekolah. Produk yang dihasilkan juga menjadi referensi tambahan bagi guru Pendidikan Jasmani Sekolah Dasar. Pembelajaran menjadi lebih bervariasi dengan menggunakan produk yang dihasilkan ini. Dalam Riset diperoleh hasil untuk ranah kognitif siswa 65\% katagori Baik Sedangkan untuk ranah afektif diperoleh hasil $73 \%$ kategori Baik, penilaian untuk ranah afektif berdasarkan sikap siswa saat pelaksanaan model permainan, hal ini terlihat dari sikap siswa dalam permainan. Ranah Psikomotorik siswa secara keseluruhan diperoleh hasil $81 \%$ katagori Baik.
\end{abstract}

Kata Kunci : Konservatif Games in Aquatic, Kebugaran Jasmani, Modifikasi, sportifitas.

\begin{abstract}
Physical Education, especially for increasing physical fitness, in the activities of implementing "Conservative Games in Aquatic", as the solution to physical education activities in the learning process at school. The products produced are also an additional reference for elementary school Physical Education teachers. Learning becomes more varied by using this product. In the research obtained results for the cognitive domain of $65 \%$ students in the category of Good While for the affective domain obtained $73 \%$ category Good, the assessment for the affective domain is based on student attitudes when implementing the game model, this can be seen from the attitude of students in the game. The overall Psychomotor domain of students is $81 \%$ Good category.
\end{abstract}

Keywords: Conservation Games in Aquatic, Physical Fitness, Modification, Sportsmanship 
http://ejurnal.budiutomomalang.ac.id/index.php/jpjok

Jp.jok (Jurnal Pendidikan. Jasmani , Olahraga dan Kesehatan)
Volume 2, Nomor 1, Nov 2018

P-ISSN 2613-9421

E-ISSN 2654-8003

\section{PENDAHULUAN}

Pendidikan jasmani merupakan alat untuk meningkatkan perkembangan gerak manusia, kemampuan badaniah, pengetahuan, unsur penalaran, menghayati nilai-nilai serta membiasakan pola hidup sehat yang bertujuan untuk merangsang pertumbuhan dan perkembangan manusia yang baik (Undang-Undang No.20 tahun 2003). Pendidikan jasmani mempunyai peranan sangat penting dalam mendampingi terselengaranya aktivitas pendidikan sebagai keseluruhan proses pembinaan manusiawi yang terjadi seumur hidup. (Djoko Pekik, 2004),. Pendidikan jasmani memberikan kesempatan pada peserta didik untuk terlibat secara langsung dalam memperoleh kegiatan serta pengalaman hidup, games, dan gerak prestasi yang diterapkan dengan terprogram, mempunayi visi dan terencana (Nurhadi Santoso, 2009).

Kecakapan dalam pengetahuan hidup itu di arahkan untuk memberikan konsep yang baik dalam menjalani hidup sampai usia tua.proses pembelajaran pendidikan jasmani mempunyai tujuan untuk mempelajari aneka ragam gerak dasar, teknis dasar permainan dan olahraga, taktik dalam permainan serta olahraga, serta nilai luhur yang ada yang meliputi nilai kebaikan dalam berolahraga yaitu sportifitas. Kelas formal yang ada di penjas tidak hanya pembelajaran yang meliputi aspek kognitif saja, tetapi di dalamnya memuat psikomotorik dan aspek afektif atau sikap. Dari keragaman yang kompleks ini menjadikan pembelajaran pendidikan jasmani menjadi sangat penting karena dalam aspek yang di kembangkan akan mendayagunakan potensi manusia yang seutuhnya dan seluruhnya. Pelaksanaannya bukan melalui pengajaran konvensional di dalam kelas yang bersifat kajian teoritis, namun melibatkan unsur fisik mental, intelektual, emosional dan sosial.

Menurut (Guntur, 2009) pengertian pendidikan jasmani lebih berupa bagian dari pendidikan secara utuh dan menyeluruh. Pendidikan jasmani bertujuan untuk mencapai proses pendidikan melalui jasmaniah dan rohaniah. Pada kenyataannya pendidikan jasmani mempunyai sumbangsih sentral dalam perkembangan kualitas pendidikan di indonesia.Tujuan pendidikan jasmani harus dibedakan dengan tujuan berolahraga, karena prestasi yang dimaksud disini adalah suatu prestasi gerak manusiawi. Gerak yang menyeluruh dari keseluruhan dalam hal gerak dasar yang lengkap dan komplit.pendidikan jasmani adalah bagian pendidikan dari pendidikanj umum, dan merupakan bagian dari sistem pendidikan (rusli lutan, 2001).

Pendidikan jasmani dapat jabarkan sebagai suatu mekanika kegiatan yang panjang dalam hal pendidikan yang diarahkan guna mencapai tujuan pendidikan melalui gerakan fisik. Ini adalah bahasan umum bahwa pendidikan jasmani sebagai satu kenyataan umum bahwa pendidikan jasmani

Bhayu Billiandri. Pengembangan” Konservatif Games In Aquatic” Untuk Peningkatan Kebugaran Jasmani dan Sportivitas Siswa Sekolah Dasar

Page | 71 
http://ejurnal.budiutomomalang.ac.id/index.php/ipjok

Jp.jok (Jurnal Pendidikan. Jasmani , Olahraga dan Kesehatan)
Volume 2, Nomor 1, Nov 2018

P-ISSN 2613-9421

E-ISSN 2654-8003

sebagai satu bagian pendidikan mempunyai bagian penting yang mengembangkan kualitas kehidupan manusia indonesia. Kesegaran jasmani adalah kemauan dan kemampuan tubuh manusia untuk melakukan penyesuaian diri terhadap beban kegiatan sehari-hari baik berupa rutinitas ataupun kegiatan yang direncakan baik di sekolah formal maupun nonformal.

Modifikasi pembelajaran aktivitas kebugaran jasmani adalah suatu kegiatan yang harus dipraktekan dalam pembelajarnnya. Contoh aktivitas pengajaran materi kebugaran jasmani adalah melalui permainan konservatif games in aquatic mempunyai maksud untuk menjadikan anak lebih baergairah, bersenang-senang dan pengembangan kemamouan diri agar proses tumbuh dan kembangnya bisa optimal, ketika mengikuti pembelajaran akuatik serta kebugaran jasmani dan menguatkan karakter dari tinjauan aspeki sportifitas.

Aktivitas air (akuatik) adalah segala jenis kegiatan yang media atau perantaranya adalah air. Kegiatan di air ini bias dilakukan di kolam renang, sungai, danau, laut, pantai, kolam. Ragam aktivitas air yang sudah dibakukan seperti renang, renang indah, loncat indah, polo air, menyelam, dayung, kano dan ragam jenis dan bentuk yang lainnya. Menurut (Yudha Febrianta, 2016) kemampuan motorik anak usia dini dapat ditingkatkan melalui aktivitas akuatik (berenang). Modifikasi pembelajaran akuatik adalah sebagai berikut: kasti in the water adalah permainan yang dilakukan di air yang di modifikasi dari permaianan kasti yang ada di darat dan dilakukan di air sebagai hasil dari modifikasinnya.. Permainan ini mkembutuhkan kerjasma yang solid di antara anggota kelompoknya, selain itu unsur kecepatan, teknik dan strategi, keakuratan lemparan juga menjadi faktor penentu dalam melaksanakan permainan ini. Polisi-polisian in the water merupakan modifikasi dari permainan polisi-polisian yang dilakukan di darat. Air menjadi media untuk melakukan kegiatan ini, pada zaman dahulu permainan ini dilakukan pada malam hari, tetapi untuk pembelajaran permainan ini dimainkan dipagi hari saat pembelajaran pendidikan jasmani dilakukan. Permainan ini sangatlah menyenangkan karena didalmnya terdapat unsur kerjasama dan taktik serta teknik yang baik dan matang dalam pelaksanaanya.

Bentengan in the water adalah permainan yang sangat menarik dilakukan, modifikasi yang dilakukan adalah yang semula dilakukan didarat di ubah dilakukan diair tanpa mengurangi unsur-unsur permainan aslinya. Permainan ini sangatmembutuhkan taktik yang tepat serta kerjasama diantara anggota kelompoknya, hal yang penting yang tidak dapat di tinggalkan dalam permainan ini dapat melihat unsur-unsur yang lain selain aspek fisik, terutama menyoroti dari aspek afeksi atau sikap, akan sangat nampak siswa 
http://ejurnal.budiutomomalang.ac.id/index.php/ipjok

Jp.jok (Jurnal Pendidikan. Jasmani , Olahraga dan Kesehatan)
Volume 2, Nomor 1, Nov 2018

P-ISSN 2613-9421

E-ISSN 2654-8003

yang bermain dengan penuh kesungguhan serta disiplin dan tak terlupakan yaitu sportifitas.

Menurut Ismaryati yang dikutip oleh (Agus Alim Sulistiono, 2015), berdasarkan fungsi khusus, kebugaran jasmani dibedakan menjadi tiga golongan yaitu: golongan berdasarkan pekerjaan, golongan berdasarkan keadaan, dan golongan berdasarkan umur. Menurut (Tri Nurharsono, 2006), kebugaran jasmani adalah kemampuan tubuh seseorang untuk melakukan tugas dan pekerjaan sehari-hari dengan giat dan waspada tanpa mengalami kelelahan yang berarti, serta masih memiliki cadangan energi untuk menghadapi hal-hal darurat yang tidak terduga sebelumnya. Menurut Mochammad Sajoto yang dikutip (Kurnia Rismaningtyas, 2016) komponen dari kebugaran jasmani terdiri dari 10 komponen, yaitu 1) Kekuatan (strength), 2) Daya tahan (Endurance), 3) Daya otot (Muscular Power), 4) Kecepatan (Speed), 5) Daya lentur (Flexibility), 6) Kelincahan (Agility), 7) Koordinasi (Coordination), 8) Keseimbangan (Balance), 9) Ketepatan (Accuracy), 10) Reaksi (Reaction).

Tujuan riset ini adalah untuk menghasilkan model permainan konservatif games in aquatic untuk meningkatkan kebugaran jasmani yang sesuai dengan karakteristik siswa sekolah dasar dalam pembelajaran pendidikan jasmani. Hasil riset ini diharapkan memberikan indikasi yang positif serta berkonstribusi seperti: bagi siswa sebagai motivasi untuk dapat mengikuti pembelajaran pendidikan jasmani lebih menyenangkan dan menggairahkan, bagi guru penjasorkes sebagai bahan dan materi untuk dapat disajikan dalam proses pembelajaran pendidikan jasmani di sekolah dasar.

\section{METODE}

Riset ini merupakan Riset pengembangan yang bertujuan membuat produk berupa role pembelajaran Aktivitas Kebugaran Jasmani melalui permainan Konservatif games in aquatic bagi siswa Sekolah Dasar (SD). Tahapan dalam Riset ini Memperguunakan tujuh tahap yaitu 1) Mengadakan Riset awal dan dikumpulkannya bukti Riset dengan cara datang langsung ke Lapangan, 2) Pengembangan Prototipe Awal, 3) Dinilai oleh ahli dengan mempergunakan satu ahli Pendidikan Jasmani dan dua ahli pembelajaran, 4) pengujian dari kelompok kecil menggunakan Angket dan Sharing serta Dinilai yang kemudian Diujikan Keakuratanya. memperbaiki produk awal, 5) Perbaikan hasil berdasarkan dari evaluasi ahli dan uji coba kelompok kecil. Perbaikan ini diterapkan terhadap produk awal yang dibuat oleh peneliti. 6) Uji coba lapangan. 7) Perbaikan produk akhir yang dilakukan berdasar hasil uji lapangan. Hasil terbaru model pembelajaran Kebugaran melalui permainan Konservatif games in aquatic bagi siswa Sekolah Dasar (SD) yang dihasilkan melalui revisi uji lapangan.

Bhayu Billiandri. Pengembangan” Konservatif Games In Aquatic” Untuk Peningkatan Kebugaran Jasmani dan Sportivitas Siswa Sekolah Dasar 
http://ejurnal.budiutomomalang.ac.id/index.php/jpjok

Jp.jok (Jurnal Pendidikan. Jasmani , Olahraga dan Kesehatan)
Volume 2, Nomor 1, Nov 2018

P-ISSN 2613-9421

E-ISSN 2654-8003

Analisis kebutuhan merupakan langkah awal dalam melakukan Riset ini. Langkah ini bertujuan untuk menentukan apakah model pembelajaran tenis meja melalui permainan Konservatif games in aquatic ini dibutuhkan atau tidak. Pada tahap ini peneliti mengadakan pengamatan di sekolah daerah Unnes dan wawancara dengan mahasiswa yang baru saja menyelesaikan PPL di Sekolah Dasar tentang pelaksanaan materi kebugaran jasmani dan akuatik. Tahapan ini dilanjutkan dengan pengujian di lapangan terhadap produk pengembangan dengan mempergunakan subjek uji coba murid Sekolah Dasar. Perbaikan produk dari hasil uji kondisi yang sesungguhnya yang telah diberikan siswa Sekolah Dasar. Hasilnya adalah produk pengembangan dari uji kelayakan di kondisi yang sebenarnya yang berupa model pembelajaran Konservatif games in aquatic.

Jumlah Siswa yang menjadi subjek penelitian dalam riset ini adalah murid kelas IV sekolah Dasar Negeri Wanurejo di Kec. Borobudur, Kabupaten Magelang Provinsi Jawa Tengah. Riset ini merupakan Riset R and D yang di hasilnya menitik beratkan pada terciptanya produk Role pembelajaran untuk materi Kebugaran Jasmani melalui Permainan di Air bagi siswa Sekolah Dasar (SD). Pada fase ini melakukan pengujian di sekolah terhadap produk yang dikembangkan dengan mempergunakan murid kelas IV Sekolah Dasar Wanurejo Kecamatan Borobudur Kab. Magelang yang berjumlah 30 siswa. Perbaikan produk dari hasil uji lapangan yang telah diuji cobakan siswa kelas IV Sekolah Dasar Kelas IV Wanurejo Kecamatan Borobudur Kab. Magelang. yang berjumlah 30 siswa. Hasil dari Percobaan Penelitian $\mathrm{R}$ and $\mathrm{D}$ ini setelah diuji lapangan yang berbentuk Role/model belajar gerak materi Kebugaran Jasmani melalui Konservatif Games in Aquatic. Uji coba produk Riset ini bertujuan untuk memperoleh efektivitas, efisiensi dan kebermanfaatan dari produk. Tahapan yang dilalui dalam pengujicoban yang telah dilakukan untuk produk dari $\mathrm{R}$ and $\mathrm{D}$ adalah sebagai berikut: Rancangan uji coba yang dilaksanakan bertujuan untuk mengetahui tingkat keefektifan dan segi kebermanfaatan produk yang dikembangkan.

Desain uji coba yang dilaksanakan terdiri dari:Sebelum produk pembelajaran yang dikembangkan diujicobakan kepada subjek, produk yang dibuat dievaluasi (validasi) terlebih dahulu oleh satu ahli Penjas, dan dua ahli pembelajaran dengan kualifikasi: adalah dosen mata kuliah Aquatik di FIK UNNES, dan guru Penjasorkes di Sekolah Dasar Kelas IV Wanurejo Kecamatan Borobudur Kab.Magelang. Fase ini adalah dari pembuatan pengembangan yang telah perbaiki dari proses perbaikan dan penilaian dari ahli kemudian dipraktekkan kepada murid kelas IV Sekolah dasar negeri Wanurejo yang berjumlah 30 siswa. Pada uji coba kelompok kecil ini menggunakan 15 siswa putra sebagai subjeknya dikarenakan jumlah yang 
ada di siswa kelas IV khususnya putra memang sangatlah terbatas. Pengambilan siswa putra sebagai subjek dilakukan dengan menggunakan sampel secara total (total sampling).

Hal Awal yang dilakukan adalah siswa dijelaskan rule dari Konservatif Games in Aquatic yang setelah itu dilakukan percobaan Konservatif Games in Aquatic. Kegiatan dilanjutkan dengan mengumpulkan siswa di ruangan untuk mengisi angket yang telah disediakan oleh peneliti. Ini mempunyai maksud untuk menguji kelompok kecil, dan kegiatan ini adalah bertujuan untuk mengetahui respon awal daripada produk yang telah dikembangkan.

Hasil data dari evaluasi satu ahli Penjas dan dua ahli pembelajaran, serta uji coba kelompok kecil tersebut dianalisis. Selanjutnya dijadikan acuan untuk merevisi produk yang telah disempurnakan. Hasil analisis uji coba kelompok kecil serta revisi produk pertama, selanjutnya dilakukan uji coba lapangan. Uji coba lapangan ini dilakukan pada siswa kelas IV Sekolah Dasar Ngijo 02 Kecamatan Gunungpati yang berjumlah 30 siswa.

Langkah awalnya adalah siswa diberikan penjelasan mengenai peraturan Konservatif Games in Aquatic, kemudian melakukan uji coba Setelah selesai melakukan uji coba siswa mengisi kuesioner tentang aktivitas yang telah dilakukan. Adapun Subjek uji coba pada Riset ini adalah sebagai berikut: Evaluator dari ahli yang terdiri satu ahli Penjas dan dua ahli pembelajaran. Uji coba kelompok kecil yang terdiri dari 15 siswa putra kelas IV Sekolah Dasar Wanurejo dipilih menggunakan sampel secara total (total sampling). Uji coba lapangan yang terdiri dari 30 siswa kelas IV Sekolah Wanurejo, sampel dipilih secara random (purposive random sampling). Angket yang dipakai untuk ahli dapat berwujud beberapa aspek yang harus diisi dan dinilai layak tidaknya. Sedangkan isi dalam angket berupa isi dari aktivitas Konservatif Games in Aquatic.

Berikut adalah kuesioner untuk kuesioner ahli :

Tabel 1 Faktor, Indikator, dan Jumlah Butir Angketr

\begin{tabular}{|c|c|l|c|}
\hline No. & Faktor & \multicolumn{1}{c|}{ Indikator } & Jumlah \\
\hline 1 & Kualitas Model & $\begin{array}{l}\text { Isi dari produk terhadap aspek keaktifan } \\
\text { siswa, kelayakan untuk diajarkan pada siswa } \\
\text { SD, dan standar kompetensi,. }\end{array}$ & 15 \\
\hline
\end{tabular}

Isi dari Pertanyaan harus dijawab oleh siswa dengan memilih jawaban "Ya" serta "Tidak". Adapun Penilaiannya meliputi aspek dari taksonomi bloom. Cara pemberian skor pada alternatif jawaban adalah sebagai berikut: 
Tabel 2 Skor Jawaban Kuesioner "Ya" dan "Tidak"

\begin{tabular}{|c|c|c|}
\hline Alternatif Jawaban & Positif & Negatif \\
\hline Ya & 1 & 0 \\
\hline Tidak & 0 & 1 \\
\hline
\end{tabular}

Berikut ini adalah faktor-faktor, indikator, dan jumlah butir ranah afektif yang akan digunakan pada responden :

Tabel 3 Faktor, Indikator, dan Jumlah Pengamatan Afektif

\begin{tabular}{|l|c|c|c|c|c|}
\hline \multirow{2}{*}{ No } & \multirow{2}{*}{ Nama } & \multicolumn{3}{|c|}{ Afektif } & \multirow{2}{*}{ Nilai } \\
\cline { 3 - 5 } & & Kerjasama & Sportifitas & Kejujuran & \\
\hline 1 & & $\sqrt{ }$ & $\sqrt{ }$ & $\sqrt{ }$ & 3 \\
\hline
\end{tabular}

Tabel 4 Faktor, Indikator, dan Jumlah pengamatan Psikomotor

\begin{tabular}{|c|c|c|c|c|c|c|c|c|c|c|c|c|c|c|c|c|c|c|}
\hline $\mathrm{N}$ & $\mathrm{Na}$ & \multicolumn{16}{|c|}{ Kebugaran Jasmani } & $\mathrm{Ni}$ \\
\hline 1. & & \multicolumn{4}{|c|}{$\begin{array}{l}\text { Kecepata } \\
n\end{array}$} & \multicolumn{3}{|c|}{$\begin{array}{l}\text { Kelinca } \\
\text { han }\end{array}$} & \multicolumn{3}{|c|}{$\begin{array}{l}\text { Kekuat } \\
\text { an }\end{array}$} & \multicolumn{2}{|c|}{$\begin{array}{l}\text { Day } \\
\text { a } \\
\text { Tah } \\
\text { an }\end{array}$} & \multicolumn{4}{|c|}{$\begin{array}{l}\text { Kelincah } \\
\text { an }\end{array}$} & 16 \\
\hline & & 1 & 2 & 3 & 4 & 1 & 2 & 3 & 1 & 2 & 3 & 1 & 2 & 1 & 2 & 3 & 4 & \\
\hline & & $\mathrm{V}$ & $\mathrm{v}$ & $\mathrm{V}$ & $\mathrm{v}$ & $\mathrm{V}$ & $\mathrm{V}$ & V & $\mathrm{v}$ & $\mathrm{v}$ & $\mathrm{v}$ & $\mathrm{v}$ & $\mathrm{v}$ & $\mathrm{v}$ & $\mathrm{v}$ & & $\mathrm{v}$ & \\
\hline
\end{tabular}

\section{HASIL DAN PEMBAHASAN}

Hasil analisis data uji coba i uji coba kelompok kecil dilakukan setelah produk konservatif games in aquatic telah mendapatkan validasi dari ahli penjas dan ahli pembelajaran. Uji coba dilakukan pada tanggal 19 mei 2018 pada siswa kelas v sd negeri wanurejo yang berjumlah 15 siswa. Tujuan dari uji coba kelompok kecil sendiri adalah untuk mengetahui dan mengidentifikasi permasalahan-permasalahan yang muncul seperti, kekurangan, kelemahan, dan apakah produk yang digunakan ini efektif atau tidak pada saat digunakan oleh siswa. Data dari uji coba kelompok kecil akan digunakan sebagai acuan revisi sebelum pelaksanaan uji coba lapangan. Uji coba kelompok kecil ini juga bertujuan untuk mengetahui tanggapan dari produk awal yang dikembangkan.

Data uji coba kelompok kecil dihimpun dengan menggunakan kuesioner untuk ranah kognitif, serta pemberian nilai secara langsung melalui pengamatan untuk ranah psikomotorik dan afektif. Hasil dari kelima ranah dijadikan menjadi satu dan dianalisis. Data kelompok kecil dianalisis 
http://ejurnal.budiutomomalang.ac.id/index.php/jpjok

Jp.jok (Jurnal Pendidikan. Jasmani , Olahraga dan Kesehatan)
Volume 2, Nomor 1, Nov 2018

P-ISSN 2613-9421

E-ISSN 2654-8003

sebagai acuan untuk revisi yang digunakan untuk uji coba lapangan. Dari data uji coba skala kecil didapatkan hasil prosentase keberhasilan $73 \%$. Hal ini tidak dapat digunakan sebagai acuan bahwa produk konservatif games in aquatic ini telah efektif atau belum, karena pada saat pelaksanaan masih ditemui kekurangan-kekurangan yang perlu diperbaiki.

Hasil analisis data uji coba ii hasil evaluasi dari ahli penjas dan ahli pembelajaran serta uji coba kelompok kecil yang telah dilakukan tahap selanjutnya adalah uji coba lapangan. Uji coba lapangan bertujuan untuk mengetahui keefektifan perubahan yang telah dilakukan pada evaluasi ahli serta uji coba kelompok kecil apakah permainan itu dapat digunakan dalam lingkungan sebenarnya. Uji coba lapangan dilakukan oleh siswa kelas iv sekolah dasar wanurejo sebanyak 30 siswa.

Data uji coba lapangan dihimpun dengan menggunakan kuesioner untuk ranah kognitif serta pengamatan secara langsung untuk ranah psikomotorik dan afektif yang mengarah kepada sportivitas. Berdasarkan hasil uji coba lapangan, didapatkan hasil yang cukup signifikan. Siswa sudah mulai dapat untuk memahami aturan yang berlaku dalam konservatif games in aquatic . Sesuai dengan kriteria yang telah ditetapkan maka aspek kualitas model konservatif games in aquatic telah memenuhi kriteria baik dan nilai rata-rata siswa mencapai $78,33 \%$.

Hal yang mendasari konservatif games in aquatic ini dapat digunakan dalam pembelajaran kebugaran jasmani di sekolah adalah siswa mampu untuk memahami aturan permainan yang diberikan, siswa dapat bergerak aktif selama pembelajaran, model yang diberikan mampu menarik minat dari para siswa, dan model pengembangan permainan sudah disesuaikan dengan tingkat kebutuhan, tahap pertumbuhan ,dan perkembangan siswa didik.

Hasil dari penelitian ini turut memberikan sumbangan pada pengembangan model pembelajaran yang bertujuan meningkatkan kebugaran jasmani siswa seperti beberapa penelitian sebelumnya yang sudah memberikan sumbangan terlebih dahulu diantaranya (Ali Ma'mun dan Ipang Setiawan, 2015) melalui permainan boi, (Dhimas Bagus Dharmawan dan Bambang Priyono, 2016) permainan SRD (Spider Run Dance), (Ramona Mathias Mae, 2017) menggunakan model tarian bonet, (Azizil Fikri, 2017) latihan sirkuit.

\section{SIMPULAN}

Simpulan peneliti memutuskan untuk mengembangkan pembelajaran kebugaran jasmani melalui konservatif games in aquatic yang sesuai dengan karakter siswa sd. Peneliti berharap produk yang dihasilkan ini dapat mempunyai sumbangsih yang baik terhadap pembelajaran pendidikan jasmani. Dapat membuat siswa lebih aktif dan bersemangat dalam proses

Bhayu Billiandri. Pengembangan” Konservatif Games In Aquatic” Untuk Peningkatan Kebugaran Jasmani dan Sportivitas Siswa Sekolah Dasar 
pembelajaran. Di dalam permainan ini siswa banyak bergerak, mulai dari melompat, berlari, jinjit dan menyesuaikan diri dengan air. Semua itu dilakukan dalam permainan. Dari 30 siswa 4 siswa yang memiliki gerak sempurna, untuk mendapatkan hasil gerakan yang sempurna sangat sulit dalam sebuah permainan.

Saran pada yang dapat diberikan berdasarkan hasil Riset ini berdasarkan kesimpulan hasil pada Riset adalah sebagai alternatif dalam pembelajaran Kesegaran di SD, disesuaikan dengan tingkat kebutuhan. Dan Model permainan ini dapat dimainkan oleh siswa di sekolah karena disesuaikan dengan karakteristik dari siswa. Bagi guru PJOK di SD diharapkan dapat mengembangkan model-model pembelajaran Kesegaran jasmani yang lebih menarik lainnya untuk digunakan dalam pembelajaran.

\section{DAFTAR PUSTAKA}

Agus Alim Sulistiono. 2015. Kebugaran Jasmani Siswa Pendidikan Dasar Dan Menengah Di Jawa Barat.Jurnal Pendidikan Dan Kebudayaan. 2015;20(2):223-233DOI 10.24832/Jpnk. V20i2.140

Ali Ma'mun Dan Ipang Setiawan. 2015. Pembelajaran Kebugaran Jasmani Melalui Permainan Boi. E-Jurnal Physical Education, Sport, Health And Recreation. 2015;4(9):2094-2099

Azizil Fikri. 2017. Upaya Meningkatkan Kesegaran Jasmani Melalui Metode Latihan Sirkuit Dalam Pembelajaran Penjasorkes Di Sma Negeri 1 Lubuklinggau. Jurnal Sportif. 2017;3(1):89-102

Depdiknas .2003. Undang-Undang Ri No.20 Tahun 2003.Tentang Sistem Pendidikan Nasional.

Dhimas Bagus Dharmawan Dan Bambang Priyono. 2016. Pengembangan Model Permainan Srd (Spider Run Dance) Dalam Pembelajaran Kebugaran Jasmani Bagi Siswa Kelas Viii Di Smp Negeri 1 Dukuhturi Kabupaten Tegal. E-Jurnal Physical Education, Sport, Health And Recreation. 2016;5(2):92-101

Djoko Pekik Irianto. (2004). Pedoman Praktis Berolahraga Untuk Kebugaran. Dan Kesehatan

Guntur. (2009). Peranan Pendekatan Andragogis Dalam Pembelajaran Pendidikan Jasmani. Jurnal Pendidikan Jasmani Indonesia (Volume 6 Nomor 2). Halaman 15 
Kurnia Rismaningtyas. 2016. Pengaruh Permaianan Bola Voli Mini Terhadap Peningkatan Kebugaran Jasmani Pecandu Narkoba. Journal of Physical Education, Sport, Health and Recreation 5 (3) (2016)

Nurhadi Santoso. (2009). Pendidikan Jasmani Di Sekolah Menengah Atas : Antara Harapan Dan Kenyataan. Jurnal Pendidikan Jasmani Indonesia (Volume 6 Nomor 2). Halaman 2-3.Pendidikan Dan Kebudayaan, Direktorat Jenderal Pendidikan Tinggi, Proyek Pembinaan

Rahmat Permana. 2016. Penguasaan Rangkaian Tes Kebugaran Jasmani Indonesia (Tkji) Melalui Diskusi Dan Simulasi (Kajian Pustaka Pemahaman Teori Dan Praktek Tkji Terhadap Mahasiswa Pgsd Umtas). Refleksi Edukatika. 2016;6(2) Doi 10.24176/Re.V6i2.603

Ramona Mathias Mae. 2017. Pengembangan Model Tarian Bonet Untuk Kebugaran Jasmani Dalam Pembelajaran Penjasorkes Di Sekolah Dasar. Jurnal Keolahragaan. 2017;5(1):81-89 Doi 10.21831/Jk.V5i1.12772

Rusli Lutan, 2000. Strategi Belajar Mengajar Penjaskes. Jakarta: Departemen Pendidikan Jasmani

Tri Nurharsono. 2006. Kumpulan Artikel Tes Dan Pengukuran Pendidikan Jasmani Dan Tes Kesegaran Jasmani Atlet. PJKR FIK UNNES Semarang.

Yudha Febrianta. 2016. Alternatif Mengembangkan Kemampuan Motorik Kasar Anak Usia Dini Dengan Aktivitas Akuatik (Berenang). Al-Athfal: Jurnal Pendidikan Anak. 2016;2(2):85-96 